\title{
A menedékkérők mentális és fizikai egészségproblémái: gyakorlatok és ajánlások
}

\author{
Kórász Krisztián dr. \\ Oxleas NHS Foundation Trust, London, Egyesült Királyság
}

\begin{abstract}
A magyar egészségügyi rendszer a példa nélkül álló migráció mértéke miatt új kihívásokkal szembesül. Az érkező menedékkérők heterogén csoportot alkotnak. Ezen egyének egészségügyi igénye változó mértékben függ a származási országtól és az érkezésük előtt kapott egészségügyi szolgáltatás minőségétől, nem beszélve a migrációs folyamat egészségre tett hatásairól. A tanulmányban leírásra kerülnek azok a nehézségek, amelyekkel a menedékkérők a szolgáltatás igénybevételekor és azok, amelyekkel a klinikusok a szolgáltatás nyújtásakor szembesülhetnek. Az összefoglaló célja, hogy biztosítsa az egészségügyi dolgozók számára azt a tudást, amely a menedékkérők kulturálisan tudatos és klinikailag informált ellátásához feltétlenül szükséges. Orv. Hetil., 2016, 157(1), 23-29.
\end{abstract}

Kulcsszavak: menedékkérő, migráns, menekült, nem dokumentált bevándorló, trauma

\section{Asylum-seekers' mental and physical health problems: practices and recommendations}

\begin{abstract}
The Hungarian health care system faces new challenges with the unprecedented increased rate of migration. Asylumseekers arriving are a heterogeneous group. Their health care needs vary depending on their country of origin and the quality of the health care they received prior to arrival, not to mention the impact of the migration process on their health. Described within this paper are the challenges an asylum seeker might face in obtaining care on arrival into the host country and the challenges clinicians face in providing that care. This review is designed to give health professionals the necessary knowledge to care for asylum-seekers in a culturally aware and clinically informed manner.
\end{abstract}

Keywords: asylum-seeker, migrant, refugee, undocumented immigrant, trauma

Kórász, K. [Asylum-seekers' mental and physical health problems: practices and recommendations]. Orv. Hetil., 2016, 157(1), 23-29.

(Beérkezett: 2015. október 6.; elfogadva: 2015. november 5.)

\section{Rövidítések}

PTSD = (posttraumatic stress disorder) poszttraumatikus stressz szindróma; UNHCR = (United Nations High Commissioner for Refugees) Egyesült Nemzetek Szervezetének Menekültügyi Fóbiztossága

Az Egyesült Nemzetek Szervezetének Menekültügyi Főbiztosságának (UNHCR - United Nations High Commissioner for Refugees) 2014-es jelentése szerint a há- borúk és az üldöztetés elől menekülők száma soha nem látott szintre nőtt a világon. Magyarországra 2014-ben legtöbben Koszovóból, illetve Afganisztánból és Szíriából érkeztek, de sokan jöttek Irakból és egyéb olyan régiókból, például a szubszaharai Afrikából, ahol háborúk, polgárháborúk dúlnak. Megjegyzendő ugyanakkor, hogy a menedékkérelmet benyújtóknak döntő többsége eddig igen rövid időn belül továbbutazott az Európai Unió valamely más tagországába [1]. A jelenlegi migráció egyértelmúen kihívások elé állítja Európát, benne 
Magyarországot, és amennyiben a mértéke nem csökken, úgy valószínűsíthető, hogy a magyar egészségügyi rendszerre a közeljövőben a jelenleginél nagyobb teher hárul.

\section{Egyezmények és fogalmi meghatározások}

Az Egyesült Nemzetek Szervezetének 1951. évi menekültügyi egyezménye a nemzetközi menekültvédelem legfontosabb dokumentuma, amelyet 1967-ben Jegyzőkönyvvel is kiegészítettek. Az Európai Unió az egyezményt magára nézve kötelezőnek ismeri el. Az egyezmény l. cikk A./(2) bekezdése kimondja, hogy menekült az a személy, aki „faji, vallási okok, nemzeti hovatartozása, illetve meghatározott társadalmi csoporthoz tartozása, avagy politikai meggyőződése miatti üldözéstől való megalapozott félelme következtében az állampolgársága szerinti országon kívül tartózkodik, és nem tudja, vagy az üldözéstôl való félelmében nem kívánja annak az országnak a védelmét igénybe venni; vagy aki állampolgársággal nem rendelkezve és szokásos tartózkodási helyén kívül tartózkodva, ilyen események következtében nem tud, vagy az üldözéstól való félelmében nem kíván oda visszatérni”. Az Egyesült Nemzetek Szerveze 1951. évi menekült meghatározása korlátozott, ugyanis nem öleli fel azon személyeket, akik például éhezés vagy természeti katasztrófa következtében menekültek el hazájukból. Ezen hiányosságokat az Európa Tanács Parlamenti Közgyúlés 27. rendes ülése is elismerte. A nyugati sajtóban a migráns (migrant) szót használják a vándorlók megnevezésére. Menedékkérő (asylum-seeker) az a személy, aki üldözéstől való megalapozott félelme következtében menekültstátuszért folyamodik. Az eljáró hatóság a tények megállapításának és értékelésének folyamata végeztével megállapítja a menedékkérő státuszát. Amennyiben a kérelmet jogosnak ítéli meg, abban az esetben a menedékkérô menekült- (refugee) státuszt kap, amennyiben azt elutasítja, abban az esetben a kérvényező nem dokumentált bevándorlóvá (undocumented immigrant) minősül át. A nem dokumentált bevándorló fogalma ugyanakkor nemcsak az elutasított menedékkéróket öleli fel, hanem mindazon személyeket, akik illegálisan léptek be az országba és nem folyamodtak menekültstátuszért, akiknek a bevándorlóstátusza rendezetlen, akik vízumuk vagy munkaengedélyük lejárta után is az országban tartózkodnak, valamint azon személyek is ideértendők, akik annak ellenére nem hagyták el az országot, hogy a menedékkérelmük elutasítását követően további fellebezésre már nem volt jogosultságuk [2]. Általánosságban elmondható, hogy a menedékkérés folyamatának kimenetele általában bináris, vagyis vagy megadják, vagy elutasítják azt. Az egyes országok menekültstátusz-elbírálása ugyanakkor nem egységes, amelyre egy, a Gazdasági Együttmúködési és Fejlesztési Szervezet államait vizsgáló tanulmány is rámutat [3]. A migráns legális státusza nagyban meghatározza az állam által biztosított egyes szociális és egészségügyi ellátások körét.

\section{A migránsok egészségügyi ellátáshoz való hozzáférése}

Az Egészségügyi Világszervezet alapszabálya és az Emberi Jogok Egyetemes Nyilatkozata értelmében a befogadó országnak biztosítania kellene, hogy a menekülteket ne érje hátrányos megkülönböztetés és hogy a menekültek a befogadó ország hasonló helyzetben lévő állampolgáraival azonos módon férjenek hozzá megfizethető, megfelelő színvonalú szakorvosi ellátáshoz. Az Európai Tanács 2003/9/EC Irányelvben határozta meg azon minimális standardokat, amelyeket a menekültek részére biztosítani kell. A migránsok legális státusza az egészségügyi ellátáshoz való jogosultságot is meghatározza. Az Európai Unión belüli országok eltérnek abban, hogy a nem dokumentált bevándorlók számára milyen szolgáltatásokat tesznek elérhetővé. Egyes országok, mint amilyen Hollandia, Portugália vagy Spanyolország, teljes körú hozzáférést biztosít a menedékkérőknek, míg más országok, mint amilyen Ausztria, Dánia, Lengyelország vagy Magyarország, csak a sürgősségi szolgáltatások igenybevételét teszi lehetővé [4]. A migránsok egészségügyi szempontból ugyanakkor potenciálisan sérülékeny csoportnak számítanak, ugyanis a migráció előttt, alatt és után is számos egészségügyi kockázatnak voltak és vannak kitéve. A menekültek, a múltban megélt üldözés és az elszenvedett traumák miatt gyakran küzdenek az általános népességénél több fizikai és mentális problémával. A migránsok csoportja a befogadó populációhoz képest eltérő betegségprofillal is rendelkezhet. A menekülteknek a megelőző és más egészségügyi ellátási programokhoz való múltbeli korlátozott hozzáférése, a jó egészséghez szükséges alapvető erőforrások hosszú ideig tartó nélkülözése miatt ugyanakkor további egészségügyi ellátási szükségleteik lehetnek [5]. Az érkező migránsok heterogén csoportot alkotnak. A származási országok különböznek egymástól etnikai, társadalompolitikai, oktatási és vallási jellegzetességeikben. A tapasztalatok azt mutatják, hogy számos menekült nem ismeri közelebbről a befogadó országok egészségügyi rendszereit. Alapvető nyelvi készségek, illetve tolmácsolási és fordítási szolgáltatásokhoz való hozzáférés nélkül gyakran nem képesek kommunikálni az egészségügyi szakemberekkel, nem kapnak beutalót a megfelelő kezelésre. Előfordulhat, hogy az egészségügyi szolgáltatók nem ismerik a menekülttek egészségbiztosításra való jogosultságának igazolására használt dokumentumtípust, és ezért megtagadják a menekültek kezelését, vagy szakorvoshoz utalják őket [5]. A nem kezelt és oltásokban nem részesült migráns nemcsak saját magára, hanem saját csoportjára és a befogadó népesség tagjaira nézve is egészségügyi kockázatot jelent.

\section{Az integráció kérdése}

Magyarország gazdasági helyzete, sajnos, nem teszi lehetővé, hogy olyan mértékben segítse a menekültek beil- 
leszkedését, mint azt némely nyugat-európai ország teszi, azonban arra az országnak mindenféleképpen törekednie kell, hogy az integrációt minél jobban elősegítse. A migránsok érkezésükkor lakhatási, foglalkoztatási és megélhetési nehézségekkel szembesülnek. Nehézséget jelenthet az új személyi kötelékek, a szociális háló kialakítása, a megszokott társadalmi-gazdasági rendszerből egy újba való átmenet, valamint a kulturális váltás is. A migráns sikeres integrációjához a befogadó ország nyelvének minimális elsajátítása, valamint a befogadó ország társadalmi, kulturális és jogi alapjainak ismerete szükséges. Ezek hiányában a migráns szociális kapcsolatait nagy valószínûséggel egyedül a származási országból érkezett többi migráns fogja jelenteni. Általában a migránsok származási országa a befogadó országétól merőben más kultúrájú, vagyis a migránsok saját kulturális értékekkel, hiedelmekkel, szokásokkal és gyakorlatokkal rendelkeznek. A kulturális különbségek magukban foglalhatják a korosztályokhoz, a családi és nemi szerepekhez, elvárásokhoz való eltérő viszonyulást. A migránsok gyakran saját országuk nevelési gyakorlataira támaszkodnak, amely gyakorlatok lehet, hogy az európai kultúrában nem megengedettek. Egyes patriarchális kultúrák a nók családon kívüli munkavállalását nem bátorítják, illetve ezen kultúrákban a nők helyzete a nyugati kultúrkörből szemlélve gyakran alávetett helyzetünek tünik. Egyes vizsgálatok szerint a menekültcsoportok körében a nők elleni erőszak gyakori $[6,7]$. Az integrációt elősegítendő az államnak biztosítania kell a nyelvtanfolyamokhoz való hozzáférést, valamint a menekültek ideiglenes munkavállalását. Szükséges olyan tanfolyamok biztosítása, amelyek elősegítik a befogadó ország társadalmi, kulturális és jogi alapjainak, ideértve a befogadó ország egészségügyi ellátási rendszerének, az egészséggel kapcsolatos jogoknak és a befogadó ország oktatási rendszerének a megismerését. Egyes kutatások azt találták, hogy a mentoringprogramok hatásosak lehetnek az integráció elősegítésében. Fontos, hogy a mentor ismerje a migráns kultúráját és ha lehet, beszélje a migráns anyanyelvét.

\section{Premigrációs, migrációs és posztmigrációs hatások}

A migránsokat vándorlásuk megkezdése előtt, annak folyamán és lezárultával olyan hatások érik, amelyek mentális és fizikai egészségükre kihatással lehetnek. Ezen hatásokat vagy tényezőket premigrációs, migrációs és posztmigrációs hatásoknak/tényezőknek nevezzük. A premigrációs tényezőkhöz soroljuk többek között a származási országban a migráns anyagi helyzetét, a származási országban kapott egészségügyi ellátás minőségét, a migráció okát és a menekült esetében az üldöztetéstől való félelmet, az üldöztetést vagy a kínzást, a sebesülést és az összeadódó traumákat vagy az ezektől való fenyegetettség érzetét. Kutatások erősítették meg a menekült nőket, férfiakat és gyerekeket ért szexuális erőszak magas prevalenciáját [8]. A szexuális erőszak nők esetében nö- veli a szexuális fertőzések, a vaginális vérzés, a húgyúti fertőzések, vetélés, koraszülés és halvaszületés előfordulását [9]. Migrációs tényezők alatt azokat a tényezőket értjük, amelyek a migránst a vándorlás folyamán érik, például rablótámadás, nemi erôszak, fizikai erôszak. Posztmigrációs tényezők alatt például strukturális tényezőket, mint amilyen a munka- és életkörülmények, menekültek esetében a menekültstátusz elbírálásának folyamata, személyes tényezóket, mint amilyen a befogadó országban töltött idő, szociális háló, nyelvi nehézségek, és akkulturális állapotot értünk, de idesorolandó a stigma és a diszkrimináció is. Posztmigrációs stresszhatás az is, ha a menekült nem tud a származási országában maradt szeretteiról vagy ha rossz híreket kap a szerettei felól.

\section{A menedékkérők mentális egészségproblémái}

Asgary és Segar megjegyzi, hogy a menedékkérők általában naivak a pszichológiai problémák tekintetében [10], és a jelentkező problémákat nem tekintik a mentális betegség(ek) megnyilvánulásainak. Sok kultúra erősen stigmatizálja a mentális egészség problémáit, amely a viselkedésbeli és érzelmi nehézségek felfedését korlátozhatja. A klinikai munkát nehezíti, hogy a pszichológiai tünetek és mentális betegségek kiértékelésére szolgáló eszközök érzékenysége és kulturális validitása gyakran gyenge. A kínzás pszichológiai következménye lehet többek között szorongás, pánikzavar, önelszigetelődés, hangulatzavar, érzelmi labilitás, irritabilitás, alvási problémák, agresszió, paranoid gondolatok, pszichózis, szerhasználat, zavartság, memóriaproblémák, koncentrációs nehézségek, fáradékonyság, személyiségváltozás és szexuális diszfunkciók [11, 12]. A kínzásnak mélyreható hosszú és rövid távú következménye lehet a poszttraumatikus stressz szindróma (posttraumatic stress disorder - PTSD), a súlyos depresszív zavar és a krónikus fájdalom szindróma. A komorbiditás gyakori. A kutatások szerint a menekültek körében az öngyilkossági kísérlet prevalenciája nagy $[13,14]$. A PTSD és a súlyos depreszszív zavar prevalenciája nagy szórást mutat: 0-99\% a PTSD és 3-85,5\% a súlyos depresszív zavar esetében [12, 15]. Egyes ajánlások szerint minden, traumát átélt menekültet a poszttraumatikus stressz szindróma tekintetében szûrni kell [16]. A szû́rést segíti a PROTECT projekt kérdőíve, amely online letölthető (http://www. parcours-exil.org/IMG/pdf/protect_project.pdf). Menekültek körében a poszttraumatikus stressz szindrómát gyakran szomatikus tünetek is kísérik, illetve a szomatikus tünetek pszichológiai eredettel rendelkeznek. A szomatizáció jelenségére a tisztázatlan fizikai panaszok, a furcsa, általános tünetek utalhatnak, mint amilyen a fáradékonyság, gyengeségérzés, hőemelkedés és a nem körülírt fájdalom. A nem nyugati kultúrkörhöz tartozó populációkban a depresszió gyakran jár együtt fizikai tünetekkel, mint amilyen a fejfájás, súlycsökkenés, szédülés, nem körülírt fájdalom, gastrointestinalis és genito- 
urinalis tünetek [17]. Patel megjegyzi, hogy a nem európai nyelvekben a depresszió szónak gyakran nincs azonos megfelelője [18], valamint hogy ezen nyelvek nem különböztetik meg tisztán egymástól a depressziót és a szorongást. A PTSD és akut stresszzavarban szenvedő betegek nagy része spontán felépül [19]. A felépülést a klinikus leginkább empátia, megnyugtatás és támogatás nyújtásával segítheti eló. A trauma és annak következményeinek feltárása a beteggel való első találkozás alkalmával nem ajánlott, kivéve, ha ez a beteg elsődleges panasza. A traumatikus emlékek felfedésének sürgetése többet árthat, mint amennyit használhat. A PTSD-tünetek csökkentésében többek között a kognitív viselkedésterápia, a narratív expozíciós terápia $[20,21]$, az EMDRterápia [22] és a csoportterápia [23] bizonyult hatásosnak.

\section{A menedékkérők fizikai egészségproblémái}

A menedékkérók általában sokfajta fizikai egészségproblémával küzdenek, amelyek között a fertőző és a nem fertőző betegségek egyaránt előfordulnak. A migránsok esetében a fertőző betegségek szûrése és menedzselése sok esetben kihívást jelent a klinikus számára, ugyanis olyan betegségek felismerése és kezelése válhat szükségessé, amelyek a befogadó ország területén nem endémiásak. A nagy tapasztalattal rendelkező migránscélországok, mint amilyen az Egyesült Királyság, iránymutatásai hasznosak lehetnek e tekintetben [24, 25]. Az Emberi Erőforrások Minisztériuma szerint $\mathrm{Ma}$ gyarországon az orvosok által valamilyen szûrővizsgálatra utalt migránsok kevesebb mint $10 \%$-a jelenik meg a szűrésen, és ezeknek is csak töredéke megy vissza a vizsgálati eredményekért [26]. Ezen a helyzeten a kormány törvénymódosítással változtatna, amely azt tenné lehetővé, hogy a tranzitzónából az ország területére való belépés feltétele egy igazolás lenne, amelyet a szürővizsgálatot végző szerv állítana ki a vizsgálati minták levételéről [27]. A migránsok körében a következő nem fertőző betegségek előfordulása gyakori : szív- és érrendszeri betegségek, csont-izom rendszeri és gastrointestinalis zavarok, krónikus fejfájás, 2-es típusú cukorbetegség [28], magas vérnyomás [28], rák, asztma és az elégtelen vagy nem megfelelő minőségű tápanyag bevitelével kapcsolatos zavarok. Gyakori akut betegségnek számítanak a légúti betegségek (gégegyulladás, hörghurut, tüdőgyulladás), emésztőrendszeri betegségek (hasmenés, hasfájás, székrekedés), allergiás megbetegedések, rühesség, tetvesség, ekcéma, hámsérülések és nőgyógyászati problémák. Gyakoriak a fog- és a periodontalis betegségek is $[29,30]$. Fontos felhívni a figyelmet arra, hogy menekülteknél az anamnézisfelvétel, a fizikai vizsgálat és a beavatkozások előhívhatnak traumatikus emlékeket, ezért a beavatkozásokat magyarázat előzze meg, a fizikai vizsgálatot pedig a szokottnál nagyobb figyelmességgel és tapintattal végezzük!

\section{Fertőző és parazitás betegségek}

Habár a parazitás fertőzések lehetnek egészen enyhe tünetúek vagy tünetmentesek, mint amilyen az ascariasis, trihuriasis, necatoriasis, ancylostomiasis [31], giardiasis, amoebiasis vagy a leishmaniasis esetében, azonban például schistosomiasis, strongyloidiasis és cysticercosis fertôzéseknél a következmények súlyosak is lehetnek [32]. Egyes vizsgálatok a strongyloidiasis gyakoriságát 23-46\%ra, míg a schistosomiasis előfordulását 44-73\%-ra teszik [33]. A strongyloidiasis gyakori Délkelet-Ázsiában [34] és Afrikában, míg a schistosomiasisos esetek 85\%-ban Afrikában fordulnak elő [35]. Az Afrikából érkező migránsok körében magas maláriás prevalenciaértékeket találtak [36]. A háborúk és polgárháborúk következtében a migránsok származási országainak egészségügyi infrastruktúrája megsemmisült, az orvosságok utánpótlása megszúnt, a klinikusok és egészségügyi dolgozók száma lecsökkent. A lakosság életkörülményei leromlottak, a kötelező védőoltások elmaradtak, aminek következtében ezen országokban a gyermekbénulás, kanyaró, mumpsz, rubeola, diftéria, pertussis, tetanusz, hepatitis A, B, C és tuberkulózisos megbetegségek száma nőtt, és esetenként járványok is felütötték fejüket, például bárányhimlő- [37], kanyaró- vagy gyermekbénulás-járvány [38]. A menekültek többsége nem rendelkezik oltási bizonyítvánnyal, de amennyiben rendelkeznek is vele, azok ritkán megbízhatóak. Az ajánlások értelmében minden, oltási bizonyítvány nélkül érkező migránst a korának megfelelő elsődleges oltásban kell részesíteni. A különböző országok immunizációs gyakorlata az Egészségügyi Világszervezet honlapján megtalálható, amely segítségünkre lehet, amikor a beteg oltási történetét ellenőrizzük (http://apps. who.int/immunization_monitoring/globalsummary). Abban az esetben, ha a migráns származási országában a tuberkulózis incidenciája nem kimagaslóan magas, a szúrés a befogadó országba érkezés után 5 évig javasolt [39]. Amennyiben a származási országban a tuberkulózis incidenciája kimagaslóan nagy, abban az esetben a latens tuberkulózisinfekció szúrése a befogadó országba érkezés után 5 éven túl is indokolt lehet [40]. Nóknél gyakori a humán papillomavírus-fertôzés, amely a méhnyakrák megelőzése céljából indokolttá teszi a szúrést. A migránsok körében a szifilisz és a HIV-fertőzöttség is gyakoribb. A Kanadába érkező migránsok HIV-fertőzöttségét vizsgálva egy kutatás azt találta, hogy a HIV-pozitív bevándorlók $70 \%$-a olyan menekült volt, akinek a származási országa a HIV tekintetében endémiás. A szubszaharai Afrikából érkezók több mint 3\%-a volt szeropozitív [41]. Lehetséges, hogy a menekültek egy része tud HIV-fertôzöttségérôl, de a kezelés lehetőségeiről nincs tudomása. A HIV-fertőzöttséggel kapcsolatos stigma és diszkrimináció is gyakran késlelteti a megfelelő kezelést.

\section{Nem fertőző betegségek}

A dél-ázsiai és afrikai etnikumok tagjai a 2-es típusú cukorbetegség tekintetében 2-4-szer nagyobb kockázat- 
nak vannak kitéve, mint a fehér etnikum tagjai [42]. Több kutatás is felhívta a figyelmet a menedékkérók elégtelen vagy nem megfelelő minőségű tápanyagbevitelére. Az újonnan érkező migránsok a befogadó országban is gyakran a már megszokott vagy kulturálisan elfogadott ételeket fogyasztják, amely növelheti a $\mathrm{B}_{12}$ vitamin-hiány [43] és a D-vitamin-hiány [44] előfordulását. A lehetséges neurológiai zavarok megelőzése érdekében egyes tanulmányok indokoltnak tartják a populáció ez irányban történő szürését. Egyes vizsgálatok ugyanakkor pozitív jelenségekre is felhívták a figyelmet. Afrika egyes területein a hütőszekrény hiánya arra készteti a lakosságot, hogy friss ételeket fogyasszon. Az ilyen területekrôl származó migránsok Európába érve általában a származási országban már megszokott étkezési gyakorlatot folytatják [45]. Az újonnan érkező migránsok körében a vashiány és a haemoglobinopathiák magas prevalenciáját is leírták. A haemoglobinopathiák növelik a vérszegénység kockázatát. Az alfa- és béta-thalassaemiák gyakoriak Afrikában, a mediterrán országokban, Indiában és Délkelet-Ázsiában, míg a sarlósejtes vérszegénység az afrikai származásúak körében gyakori.

\section{A női nemi szervek csonkítása}

A női nemi szervek csonkítása mélyen gyökerezik egyes kultúrákban. E gyakorlat elsősorban Afrika nyugati, keleti és északkeleti területeire, valamint a Közel-Kelet és Ázsiai egyes országaira jellemző. Ezeknek az országoknak a kulturális hiedelme azt tartja, hogy a női nemi szervek csonkítása segíti a szüzesség megtartását, meggátolja a promiszkuitást és biztosítja a házasságra való képességet. Más hiedelmek szerint a csonkítás elősegíti a tisztaságot és higiéniát. Egyes nők úgy tartják, hogy amennyiben a klitorisz nem kerül eltávolításra, úgy a lány nem válhat érett nôvé, vagy nem lehet a társadalom teljes jogú tagja. A gyakorlatot a köznyelvben női körülmetélésnek vagy női cirkumcíziónak, míg az orvosi nyelvben genitális vágásnak vagy a nemi szervek csonkításának nevezik. A beavatkozás a külső nemi szervek részleges vagy teljes eltávolítását jelenti, amely beavatkozást általában 4 és 10 év közötti lányokon hajtják végre. A genitális vágás késői következményei húgyúti betegségek, hegesedés, fájdalom, meddőség, csökkent szexuális funkció és pszichológiai következmények lehetnek. A női nemi szervek csonkításával kapcsolatban a klinikusnak nyílt beszélgetést kell folytatnia a beteggel. A beteg figyelmét fel kell hívnia a genitális vágás lehetséges jövőbeni negatív következményeire vagy amennyiben a jelen problémák öszszeköthetőek a genitális vágás tényével, úgy ezt közölni kell. A női nemi szervek csonkítása esetében a terhesség és szülés menedzselésére az Egészségügyi Világszervezet iránymutatása megtalálható a szervezet honlapján (http://www.who.int/gender/other_health/teachersguide.pdf) [46].

\section{Kulturális vonatkozások - az orvos-beteg találkozás}

A vizsgálatok arra hívják fel a figyelmet, hogy a nyugatitól eltérő kultúrákból érkezők gyógyítása nagyobb sikerrel jár, ha a beteg kulturális hiedelmeit is tekintetbe veszik. A hagyományos kultúrákban a vallásnak, a vallási gyakorlatoknak és a vallási vezetőknek meghatározó a szerepe az egészségről való gondolkodásban és a gyógyításban. Amennyiben a származási országban a migráns betegsége esetén először a vallási vezetőhöz vagy hagyományos gyógyítóhoz fordult tanácsért, abban az esetben nagy valószínúséggel a befogadó országban is hasonlóképpen fog eljárni. E betegségút követését valószínúsíti az is, ha a migráns nem beszéli a befogadó ország nyelvét, vagy ha nem ismeri a nyugati egészségügyi rendszert. A hagyományos orvoslás igénybevétele ezen kultúrákban mindennapos gyakorlat. Orvosság felírása előtt célszerü a betegnél rákérdezni, hogy vajon használ-e házi orvosságot vagy kiegészítő gyógykészítményt, ugyanis ezek kölcsönhatásba léphetnek a felírni kívánt gyógyszerrel, módosítva annak metabolizmusát. A migránsok gyakran olyan kultúrából érkeznek, ahol az egészség és betegség megközelítése legtöbbször közösségi, vagyis a beteg felépülésében a családnak, barátoknak, szomszédoknak és a közösségnek kulcsszerep jut. A migránsok kultúrájában a tiszteletadás része lehet, hogy a kezdeményezést mindig átengedik a tekintélyszemélynek, ami azt eredményezheti, hogy nem intéznek kérdéseket az orvoshoz, csak az orvos által feltett kérdésekre válaszolnak. Bizonyos kultúrákban egyes viselkedési formák társadalmilag elfogadottak és tipikusak, míg ugyanezen viselkedések más kultúrákban nem azok. A klinikusnak kihívást jelenthet a kulturálisan normális és a patológiás válaszreakció egymástól való megkülönböztetése. A betegség(ek) diagnózisát és kezelését nehezítheti, ha a klinikus nincs tisztában az eufeminizmusokkal vagy azokkal a kollektív elkerülő mechanizmusokkal, amelyeket a közösség bizonyos traumák esetén alkalmaz. Erre példa a darfúri genocídium túlélőinek esete. A közösség tagjai beszámolóikban úgy írták le a nőket, mint akik „távol voltak pár napig”. Közvetlenül nem mondták ki, hogy ezeket a nőket elrabolták és megerőszakolták a Janjaweed-felkelők. A nemi erőszak megtörténtének direkt kimondása ezen női áldozatok férjeik és családjaik általi kitagadását vonta volna maga után [47]. A muzulmán beteg a kezelés előtt és alatt gyakran kikéri vallási vezetője tanácsát, aki egy precedens nélküli helyzetben vagy új probléma felmerülése esetén az iszlám vallási jogban, a Sari'aban keres választ a felmerülő problémára. A muzulmánok a Ramadán havában napkeltétől napnyugtáig tartó böjtöt tartanak, amikor is az evéstől és ivástól tartózkodniuk kell. A 14 éven aluli gyermekek, a terhes és szoptatós anyák, valamint a betegek felmentést kapnak a böjt alól. Az iszlám kultúrától idegen az ellentétes nemű idegenek közti közvetlen kapcsolat, a kézfogás vagy hogy a muzulmán nő a férfi orvossal egyedül legyen a vizsgá- 
lószobában. A közvetlen szemkontaktus és a kérdésekre adott direkt válaszadás sem megszokott. Ne kezdeményezzünk kézfogást ellentétes nemü muzulmán személylyel. A muszlim kultúrában a köszöntést szívre tett kézzel fejezik ki. A hatékony felismerés és kezelés megkövetelheti professzionális tolmácsok vagy kultúrbrókerek alkalmazását, akik segíthetik a beteg problémáinak azonosítását, segíthetnek a betegséghiedelmek értelmezésében, és segíthetik a betegség társadalmi okait és következményeit kezelni [48].

\section{Következtetések}

Az UNHCR kiadványa, amely „A menekültek áttelepítése: nemzetközi kézikönyv a befogadás és integráció előmozdításához" címet viseli, a menekültek egészséges életvitele megkezdésének tervezésével és támogatásával kapcsolatos számos ajánlást fogalmaz meg [49]. A befogadó országok számára ajánlja többek között az egészségügyi szolgáltatók kapacitásépítését a szakellátás, a tanácsadás és más szolgáltatások terén, képzési és oktatási programok szervezését, közösségi alapú tolmácsolási szolgáltatások kiépítését, kultúraközi közvetítók alkalmazását, a menekültek számára nyelvtanulási és kulturális ismeretterjesztési tanfolyamok biztosítását és a közösségi alapú szolgáltatások fejlesztésének támogatását. Annak érdekében, hogy a menedékkérők kulturálisan tudatos és klinikailag informált ellátásban részesüljenek, az egészségügyi dolgozónak ismernie kell a migránsokat érő hatásokat, ismernie kell a migránsok lehetséges speciális szükségleteit és a kulturális vonatkozásokat. A klinikusok hasznát vehetik az egészségügyi szűrési és kezelési iránymutatásoknak és a migránsok nyelvére lefordított betegtájékoztatóknak is.

Anyagi támogatás: A közlemény megírása anyagi támogatásban nem részesült

A szerző a cikk végleges változatát elolvasta és jóváhagyta.

Érdekeltségek: A szerzőnek nincsenek érdekeltségei.

\section{Irodalom}

[1] UNHCR: Global Trends 2014. http://unhcr.org/556725e69. $\mathrm{html}$

[2] Refugee Council: Terms and definitions. Glossary of terminology relating to asylum seekers and refugees in UK. http://www.refugeecouncil.org.uk/glossary

[3] Hatton, T. J.: Seeking asylum: Trends and policies in the OECD Centre for Economic Policy Research, London, 2011. http:// www.voxeu.org/sites/default/files/file/Hatton\%20Seeking\%20Asylum.pdf

[4] Karl-Trummer, U., Novak-Zezula, S., Metzler, B.: Access to health care for undocumented migrants in the EU. Eurohealth, 2010, 16(1), 13-16.
[5] United Nations High Commissioner for Refugees: Integration of refugees in Central Europe. [ENSZ Menekültügyi Főbiztosság: Menekültintegráció Közép-Európában - Háttéranyag.] ENSZ Menekültügyi Fớbiztosság Közép-európai Regionális Képviselet, Budapest, 2009. http://www.unhcr-centraleurope.org/_assets/files/content/what_we_do/pdf_hu/promoting_integration/UNHCR-Integration_note-HUN_version-screen.pdf [Hungarian]

[6] Khawaja, M., Barazi, R.: Prevalence of wife beating in Jordanian refugee camps: Reports by men and women. J. Epidemiol. Community Health, 2005, 59(10), 840-841.

[7] Maziak, W., Asfar, T.: Physical abuse in low-income women in Aleppo, Syria. Health Care Women Int., 2003, 24(4), 313-326.

[8] Swiss, S., Giller, J. E.: Rape as a crime of war. A medical perspective. JAMA, 1993, 270(5), 612-615.

[9] Campbell, J., Jones, A. S, Dienemann, J., et al.: Intimate partner violence and physical health consequences. Arch. Intern. Med., 2002, 162(10), 1157-1163.

[10] Asgary, R., Segar, N.: Barriers to health care access among refugee asylum seekers. J. Health Care Poor Underserved, 2011, 22(2), 506-522.

[11] Priebe, S., Jankovic Gavrilovic, J., Bremner, S., et al.: Psychological symptoms as long-term consequences of war experiences. Psychopathology, 2013, 46(1), 45-54.

[12] Steel, Z., Chey, T., Silove, D., et al.: Association of torture and other potentially traumatic events with mental health outcomes among populations exposed to mass conflict and displacement: a systematic review and meta-analysis. JAMA, 2009, 302(5), 537549.

[13] Ferrada-Noli, M., Asberg, M., Ormstad, K., et al.: Suicidal behavior after severe trauma. Part 1: PTSD diagnoses, psychiatric comorbidity, and assessments of suicidal behavior. J. Trauma Stress, 1998, 11(1), 103-112.

[14] Goosen, S., Kunst, A.E., Stronks, K., et al.: Suicide death and hospital-treated suicidal behaviour in asylum seekers in the Netherlands: a national registry-based study. BMC Public Health, 2011, 11,484 .

[15] Fazel, M., Wheeler, J., Danesh, J.: Prevalence of serious mental disorder in 7000 refugees resettled in western countries: a systematic review. Lancet, 2005, 365(9467), 1309-1314.

[16] Hauck, F. R., Corr, K. E., Lewis, S. H., et al.: Health and health care of African refugees: an underrecognized minority. J. Natl. Med. Assoc., 2012, 104(1-2), 61-71.

[17] Kirmayer, L. J.: Cultural variations in the clinical presentation of depression and anxiety: implications for diagnosis and treatment. J. Clin. Psychiatry, 2001, 62(Suppl. 13), 22-28.

[18] Patel, V.: Cultural factors and international epidemiology. Br. Med. Bull., 2001, 57, 33-45.

[19] Kessler, R. C., Sonnega, A., Bromet, E., et al.: Posttraumatic stress disorder in the National Comorbidity Survey. Arch. Gen. Psychiatry, 1995, 52(12), 1048-1060.

[20] Schauer, M., Neuner, F., Elbert, T.: Narrative exposure therapy. A short-term intervention for traumatic stress disorders. 2nd ed. Hogrefe \& Huber, Cambridge, 2011.

[21] Neuner, F., Schauer, M., Klaschik, C., et al.: A comparison of narrative exposure therapy, supportive counseling, and psychoeducation for treating posttraumatic stress disorder in an African refugee settlement. J. Consult. Clin. Psychol., 2004, 72(4), 579587.

[22] Shapiro, F.: Eye movement desensitization and reprocessing (EMDR): Basic principles, protocols, and procedures. Guilford Press, New York, 2001.

[23] Tucker, S., Price, D.: Finding a home: Group psychotherapy for traumatized refugees and asylum seekers. Eur. J. Psychother. Couns., 2007, 9(3), 277-287.

[24] Public Health England: Migrant Health Guide. http://webarchive.nationalarchives.gov.uk/20140714084352/ http:/www.hpa.org.uk/MigrantHealthGuide/ 
[25] Public Health England: Vaccination of individuals with uncertain or incomplete immunisation status. https://www.gov.uk/government/uploads/system/uploads/attachment_data/ file/463433/HPA-algorithm-September-2015-04b.pdf

[26] One out of ten asylum-seekers participates in medical examination. [Tízbő́l egy migráns megy el orvosi vizsgálatra.] Inforadio, October 4, 2015. www.inforadio.hu/hir/belfold/tizbol-egymigrans-megy-el-orvosi-vizsgalatra-762589 [Hungarian]

[27] $H V G$ : Obligatory medical screening for asylum-seekers may come. [Jöhet a menekültek kötelező szû́rővizsgálata.] HVG, Szeptember 29, 2015. www.hvg.hu/itthon/20150929_ johet_a_menekultek_kotelezo_szurovizsgalata [Hungarian]

[28] Kinzie, J. D., Riley, C., McFarland, B., et al.: High prevalence rates of diabetes and hypertension among refugee psychiatric patients. J. Nerv. Ment. Dis., 2008, 196(2), 108-112.

[29] Cote, S., Geltman, P., Nunn, M., et al.: Dental caries of refugee children compared with US children. Pediatrics, 2004, 114(6), e733-e740.

[30] Garcia, R. I., Cadoret, C. A., Henshaw, M.: Multicultural issues in oral health. Dent. Clin. North Am., 2008, 52(2), 319-332.

[31] Bethony, J., Brooker, S., Albonico, M., et al.: Soil-transmitted helminth infections: ascariasis, trichuriasis, and hookworm. Lancet, 2006, 367(9521), 1521-1532.

[32] Caruana, S. R., Kelly, H. A., Ngeow, J. Y., et al.: Undiagnosed and potentially lethal parasite infections among immigrants and refugees in Australia. J. Travel Med., 2006, 13(4), 233-239.

[33] Posey, D. L., Blackburn, B. G., Weinberg, M., et al.: High prevalence and presumptive treatment of schistosomiasis and strongyloidiasis among African refugees. Clin. Infect. Dis., 2007, 45(10), 1310-1315.

[34] Gyorkos, T. W., Genta, R. M., Viens, P., et al.: Seroepidemiology of strongyloides infection in the Southeast Asian refugee population in Canada. Am. J. Epidemiol., 1990, 132(2), 257-264.

[35] Chitsulo, L., Engels, D., Montresor, A., et al.: The global status of schistosomiasis and its control. Acta Trop., 2000, 77(1), 41-51.

[36] Marangi, M., Di Tullio, R., Mens, P. F., et al.: Prevalence of Plasmodium spp. in malaria asymptomatic African migrants assessed by nucleic acid sequence based amplification. Malar. J., 2009, 8 , 12.

[37] Kjersem, H., Jepsen, S.: Varicella among immigrants from the tropics, a health problem. Scand. J. Soc. Med., 1990, 18(3), $171-174$.
[38] Arie, S.: Polio outbreak leads to calls for a "vaccination ceasefire" in Syria. BMJ, 2013, 347, f6682.

[39] American Thoracic Society: Targeted tuberculin testing and treatment of latent tuberculosis infection. MMWR Recomm. Rep., 2000, 49(RR-6), 1-51

[40] Walter, N. D., Painter, J., Parker, M., et al., for the Tuberculosis Epidemiologic Studies Consortium: Persistent latent tuberculosis reactivation risk in United States immigrants. Am. J. Respir. Crit. Care Med., 2014, 189(1), 88-95.

[41] Zencovich, M., Kennedy, K., MacPherson, D. W., et al.: Immigration medical screening and HIV infection in Canada. Int. J. STD AIDS, 2006, 17(12), 813-816.

[42] Creatore, M. I., Moineddin, R., Booth, G., et al.: Age- and sex-related prevalence of diabetes mellitus among immigrants to Ontario, Canada. CMAJ, 2010, 182(8), 781-789.

[43] Stabler, S. P., Allen, R. H.: Vitamin $\mathrm{B}_{12}$ deficiency as a worldwide problem. Annu. Rev. Nutr., 2004, 24, 299-326.

[44] Skull, S. A., Ngeow, J. Y., Biggs, B. A., et al.: Vitamin D deficiency is common and unrecognized among recently arrived adult immigrants from The Horn of Africa. Intern. Med. J., 2003, $33(1-2), 47-51$.

[45] Simmelink, J., Lightfoot, E., Dube, A., et al.: Understanding the health beliefs and practices of East African refugees. Am. J. Health Behav., 2013, 37(2), 155-161.

[46] World Health Organization: Female genital mutilation: a handbook for frontline workers. World Health Organization, Geneva, Switzerland, 2000

[47] Meffert, S. M., Musalo, K., McNiel, D. E., et al.: The role of mental health professionals in political asylum processing. J. Am. Acad. Psychiatry Law, 2010, 38(4), 479-489.

[48] Kirmayer, L. J., Narasiah, L., Munoz, M., et al.: Common mental health problems in immigrants and refugees: general approach in primary care. CMAJ, 2011, 183(12), E959-E967.

[49] United Nations High Commissioner for Refugees: Refugee resettlement: an international handbook to guide reception and integration. UNHCR, 2011.

(Kórász Krisztián dr.,

25 John Wilson Street, London, SE18 6PZ Egyesült Királyság e-mail: krisztian.korasz@oxleas.nhs.uk) 